\title{
Acute Abdomen Due to Uncontrolled Use of Warfarin: Spontaneous Intra-abdominal
}

\author{
Kontrolsüz Warfarin Kullanımına Bağlı Akut Karın Kliniği: Spontan Intra- \\ abdominal Kanama
}

\author{
Fatih Dal, Hasan Ökmen, Turgay Erginel, Meltem Küçük Yılmaz, Önder Akkuş, Serkan Sarı \\ University of Health Sciences, İstanbul Training and Research Hospital, Clinic of General Surgery, Istanbul, Turkey
}

\section{Abstract}

Warfarin is an oral anticoagulant, which is commonly used in the treatment and prophylaxis of thromboembolic conditions. Bleeding is the primary adverse effect associated with warfarin. The majority of warfarin-related bleedings are spontaneous minor hemorrhages occurring in the subcutaneous or intramuscular tissues and can be treated by decreasing the dose of oral anticoagulants. However, although rare, it is possible to encounter spontaneous major bleedings with increased risk of mortality. Conservative approach is the preferred initial therapy for hemodynamically stable patients with major intraabdominal hemorrhages that we define as the intermediate group patients. Nevertheless, surgery is required for hemodynamically unstable patients with acute abdominal pain in cases of ongoing active hemorrhage, generalized peritonitis, obstruction, acute abdomen, intestinal ischemia, and perforation. In this article, we present a rare case of acute abdomen and spontaneous intra-abdominal hemorrhage resulting from uncontrolled use of warfarin and a new classification requirement.

Keywords: Warfarin, acute abdomen, bleeding
Öz

Warfarin, yaygın olarak tromboembolik durumların tedavi ve profilaksisinde kullanılan oral antikoagülan bir ajandır. En önemli yan etkisi kanamadır. Çoğu deri altı veya kas dokusu içine olan, spontan minör kanamalar olup, antikoagülanın dozu azaltılarak tedavi edilebilir. Klinikte nadiren mortalite riski yüksek, spontan majör kanamalar görülebilir. Tedavide, orta düzey grup olarak tanımladığımız; hemodinamik olarak olarak stabil, majör intra-abdominal kanamalarda, başlangıç tedavisi öncelikli olarak konservatif yaklaşımdır. Ancak hemodinamik olarak stabil olmayan, başlangıç koservatif tedaviye rağmen, devam eden aktif hemoraji, jeneralize peritonit, obstrüksiyon, akut karın olgularında, intestinal iskemi düşünülen ve perforasyon saptanan durumlarda cerrahi girişim gerekmektedir. Bu yazımızda, kontrol edilemeyen warfarin kullanımıyla ortaya çıkan nadir bir akut karın ve spontan intra-abdominal kanamayı ve yeni bir sınıflama gerekliliğini sunuyoruz.

Anahtar Sözcükler: Warfarin, akut karın, hemoraji

The most significant adverse effect associated with warfarin is mostly spontaneous minor subcutaneous or intramuscular bleedings; nevertheless, warfarin may rarely cause intraabdominal hemorrhages with higher mortality risk $(3,4)$.

Whereas decreasing the dose of OACs is effective in the treatment of minor bleedings, surgical and conservative treatment methods are preferred in case of major spontaneous intra-abdominal bleedings $(2,3)$. Surgery is applied for patients, who are suspicious for intestinal ischemia or perforation; or for those, whose active bleeding and acute abdomen manifestations 
continue during monitoring (5). In the literature, there are the cases of hemodynamically stable patients with no additional complication other than major spontaneous intra-abdominal hemorrhage and acute abdominal pain who could be treated with conservative approach without a need for surgical intervention $(3,6)$. In the literature, minor and major bleedings are classified as hemorrhage, but major hemorrhage has an intermediate patient group that is controlled by medical treatment without surgical treatment.

Here, we aimed to present a patient, who stayed hemodynamically stable despite suffering from spontaneous intra-abdominal hemorrhage and acute abdominal pain and did not develop any additional complication and, to discuss treatment methods that can be applied for such patients who are classified as the intermediate group.

\section{Case}

A 75-year-old female patient presented to the emergency department due to ecchymosis present for one week and accompanied by gradually advancing abdominal pain for the last four days (Figure 1). According to her medical records, the patient had hypertension (HT) and was started on warfarin therapy (posology: coumadin ${ }^{\circledR}$ $5 \mathrm{mg} /$ day) two months ago due to peripheral vascular insufficiency. However, she did not have necessary control examinations on regular basis. On admission, her arterial blood pressure was $120 / 60 \mathrm{~mm} / \mathrm{Hg}$, pulse rate was $80 / \mathrm{min}$, respiratory rate was $18 / \mathrm{min}$ and body temperature was $36.3^{\circ} \mathrm{C}$. Systemic examination revealed abdominal rebound and tenderness at the umblical region and ecchymosis at the medial of the left femur and left patella. The results of the laboratory tests performed on admission were as follows: white blood cell (WBC): $8.770 / \mathrm{mm}^{3}$, hemoglobin $(\mathrm{Hb}): 9.1 \mathrm{~g} / \mathrm{dL}$ (12.2-16.2), hematocrit (Hct): $28.2 \%$ (37.7-

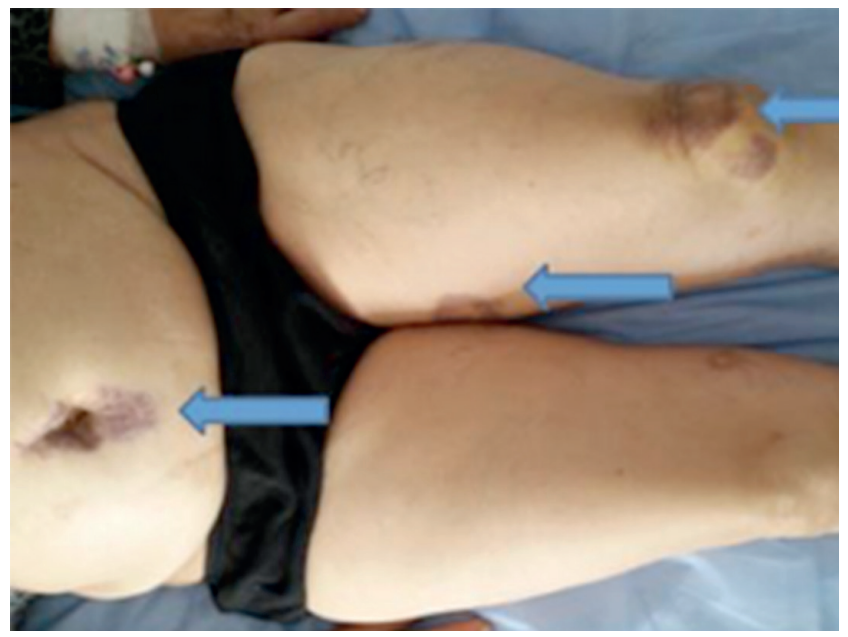

Figure 1. Skin manifestations
47.9\%), urea: $82 \mathrm{mg} / \mathrm{dL}(17-43)$, creatinine $(\mathrm{Cr}): 1.28$ $\mathrm{mg} / \mathrm{dL}(0.51-0.95)$, activated partial thromboplastin time (aPTT): 149.1/sec (20.8-35), prothrombin time (PT) 112.5/ sec (10.4-14.6), and INR: $>9$-too high to be measured(normal: 0.8-1.2). There was excessive intra-abdominal fluid accumulation on abdominal ultrasonography (USG). Abdominopelvic computed tomography (CT) indicated significant heterogeneity in mesenteric fat planes, diffuse wall thickening in ileal segments and excessive free fluid in all peritoneal recesses (Figure 2). Following her written consent, the patient was hospitalized with the preliminary diagnosis of intra-abdominal hemorrhage secondary to uncontrolled warfarin therapy. Therefore, warfarin therapy was discontinued. The patient was administered vitamin $\mathrm{K}$, proton pump inhibitor and two units of erythrocyte suspension, and five units of fresh frozen plasma (FFP) in addition to fluid resuscitation. On the $2^{\text {nd }}$ day of the treatment, physical examination findings of the patient disappeared. The vital findings of the patient were stable. On the $2^{\text {th }}$ day of hospitalization, the laboratory findings were as follows: WBC: $7.380 / \mathrm{mm}^{3}, \mathrm{Hb}: 8.7 \mathrm{~g} / \mathrm{dL}$, Hct: $26.6 \%$, urea: $17.1 \mathrm{mg} / \mathrm{dL}, \mathrm{Cr}: 0.64 \mathrm{mg} / \mathrm{dL}$, aPTT: $25.3 / \mathrm{sec}$, PT: $12.2 / \mathrm{sec}$, and INR: 0.9. On the control abdominopelvic CT scan, there was a significant decrease in the amount of intra-abdominal fluid (Figure 3). On the $3^{\text {rd }}$ day of the treatments, as clinical manifestations improved, oral feeding was started and low molecular weight heparin (LMWH) (posology: clexane ${ }^{\circledR}: 0.4 \mathrm{~mL} /$ day) was added to the medical therapy. On the $4^{\text {th }}$ day of hospitalization, the laboratory findings were as follows: WBC: $5.990 / \mathrm{mm}^{3}$, $\mathrm{Hb}: 9.9$ g/dL, Hct: 30.7\%, urea: $21.1 \mathrm{mg} / \mathrm{dL}, \mathrm{Cr}: 0.62 \mathrm{mg} /$ dL, aPTT: $26.6 / \mathrm{sec}$, PT: $11.8 / \mathrm{sec}$ and INR: 0.9. Therefore, the patient was discharged to continue the LMWH therapy with regular control examinations.

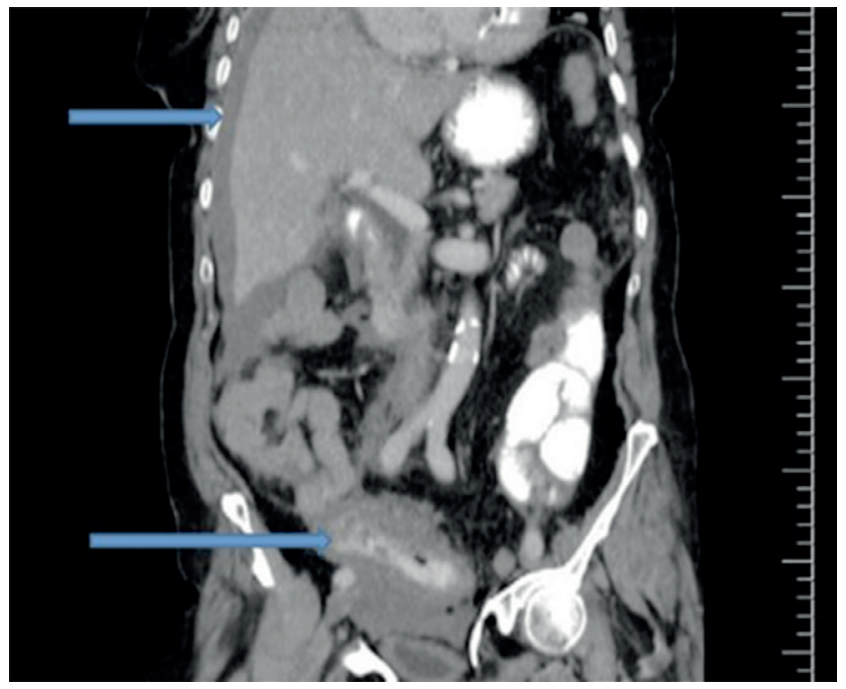

Figure 2. Abdominopelvic computed tomography image of pretreatment 


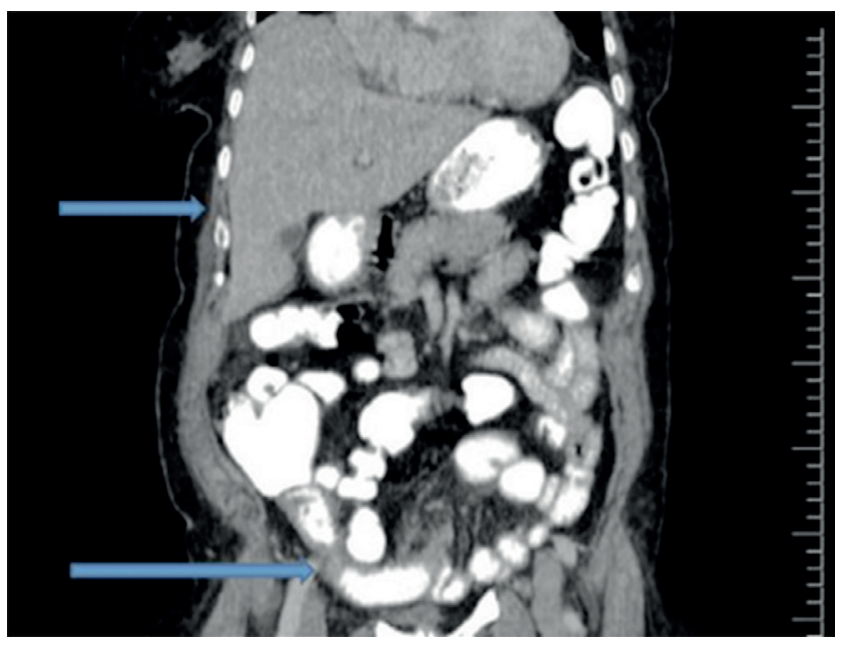

Figure 3. Abdominopelvic computed tomography image of the $2^{\text {nd }}$ day of the medical treatment

\section{Discussion}

Bleeding is the primary complication of warfarin therapy with an annual incidence of $7.6 \%$ (7). Even though warfarin-related bleeding is mostly subcutaneous or intramuscular and can be managed by reducing the dose of warfarin, there is a risk for gastrointestinal, intracranial, retroperitoneal and intraperitoneal bleeding, which can be life threatening $(3,4)$. In the literature, the followings have been reported to be the factors increasing the risk for bleeding associated with warfarin usage: dose of warfarin, advanced age, ulcer, HT, cancer, cerebrovascular event, history of surgery and history of gastrointestinal bleeding $(3,7-9)$. Our case was similar to the cases reported in the published literature because of her advanced age, history of HT and INR level above the therapeutic level. The INR level in our patient was above nine and beyond the measurable limits.

Acute abdominal pain may occur in patients receiving warfarin and suffering from non-traumatic intra-abdominal hemorrhage. Coagulation parameters are usually disrupted in such patients. However, it should be always kept in mind that intra-abdominal hemorrhage can develop even in the presence of normal coagulation parameters (6). In patients presenting with acute abdominal pain, abdominal USG and CT are the most commonly preferred imaging methods employed for a definitive diagnosis. Although USG is an easily applicable method, abdominal CT has higher sensitivity (5). Abdominopelvic CT in our patient demonstrated significant heterogeneity in mesenteric fatty planes, diffuse wall thickening in ileal segments and excessive free fluid in all peritoneal recesses. Additionally, all coagulation parameters were disrupted as reported in the literature. Nevertheless, the vital signs of the patient were stable despite acute abdominal pain.
In the case of hemorrhages associated with the use of warfarin, it is generally sufficient to adjust the dose of OAC for the treatment of hemodynamically stable minor bleedings, which are not accompanied by any disorder other than skin manifestations. If vitamin $\mathrm{K}$ is to be added to the therapy, it should be noted that INR response may be seen 24 hours after oral intake and within four-six hours after intravenous administration (2). In intermediate group patients, who are hemodynamically stable but having major intra-abdominal hemorrhage, conservative approach may be applied as the initial treatment. At the first phase of the treatment, relevant OAC agent is discontinued, and FFP and intravenous vitamin $\mathrm{K}$ are introduced. However, such patients may possibly require blood transfusion without a need for surgical intervention. Also, prothrombin complex concentrations can be used to reverse the effects of OACs if rapid INR response is desired $(2,3,6)$. Surgical intervention is required for hemodynamically unstable patients with acute abdominal pain in cases of ongoing active hemorrhage, generalized peritonitis, obstruction, acute abdomen, intestinal ischemia, and perforation (5). Nevertheless, our patient did not show any complication that may necessitate surgery. She was started oral feeding on the $2^{\text {nd }}$ day of conservative therapy and was discharged from the hospital on the $4^{\text {th }}$ day with suggestions for regular control examinations.

We believe that it is possible to successfully treat and follow up hemodynamically stable patients, who are intermediate group without using operative methods and spontaneous intra-abdominal hemorrhages may be classified as minor, intermediate, and major. However, the number of the studies -excluding the case reports -addressing the issue is limited in the published literature. Therefore, we need reports on larger series to draw more accurate conclusions.

\section{Ethics}

Informed Consent: Written informed consent was obtained from patient.

Peer-review: Externally peer-reviewed.

\section{Author Contributions}

Concept: F.D., H.Ö. Design: F.D., T.E., S.S. Data Colection or Processing: T.E., M.K.Y., Ö.A. Analysis or Interpretation: F.D., H.Ö. Literature Search: M.K.Y., Ö.A. Writing: F.D., S.S.

Conflict of Interest: No conflict of interest was declared by the authors.

Financial Disclosure: The authors declared this study has received no financial support

\section{References}

1. Oake $N$, Jennings $A$, Forster AJ, Fergusson D, Doucette $S$, van Walraven C. Anticoagulation intensity and outcomes among 
patients prescribed oral anticoagulant therapy: a systematic review and meta-analysis. CMAJ 2008;179;235-44.

2. Kara H, Bayır A, Ak A, Değirmenci S, Serin H. Skin hemorrhage due to uncontrolled warfarin therapy: Case report. Med J Bakırkoy 2015;11:170-2.

3. Ölmez A, Berkeşoğlu $M$, Dağ A, Eker E. Intraabdominal Hemorrage Associated With warfarine Usage 2 Case Reports. Causapedia 2015;4:1236.

4. Polat C, Dervisoglu A, Güven $H$, et al. Anticoagulantinduced intramural intestinal hematoma. Am J Emerg Med 2003;21:208-11.

5. Ünek T, Egeli T, Sevinç Ail, Arslan Ç. Spontaneous intestinal intramural hematoma due to warfarin use: Report of Two cases. Ulus Cerrahi Derg 2011;27:167-70.
6. Kar H, Peker $\mathrm{Y}$, Cin N, et al. Intra abdominal hemorrhage due to uncontrolled warfarin therapy: Two case reports. Marmara Med J 2010;23:377-81.

7. Palareti G, Leali N, Coccheri S, et al. Bleeding complications of oral anticoagulant treatment: an inception-cohort, prospective collaborative study (ISCOAT). Italian Study on Complications of Oral Anticoagulant Therapy. Lancet 1996;348:423-8.

8. Levine MN, Raskob G, Beyth RJ, Kearon C, Schulman S. Hemorhagic Complications of Anticoagulant Treatment: the Seventh ACCP Conference on Antithrombotic and Thrombolytic Therapy. Chest 2004;126:287-310.

9. Makris M, Watson HG. The management of coumarininduced over-anticoagulation annotation. $\mathrm{Br} J$ Haematol 2001;114:271-80. 